\title{
The Leadership Communication Style on Political Parties in the Digital Era
}

\section{Sabena}

Fakultas Ilmu Komunikasi Universitas Mercu Buana, Indonesia

Email: bena_rangkuti@mercubuana.ac.id

\begin{abstract}
This studyis entitled the leadership communication style on political parties. This study aims to find out andanalyzehow the leadership communication style participate in the politicial world, especiallyPartai Amanat Nasional. It is expected that it can give a contribution in the form of input to the activity of political communication. In addition, this study is expected to describe the various findings that explain what communication activites are recommendedand not recommended. Thus, this study can help the political practitioners in conducting the evaluation of their political communication activities. The concepts used as the basis for this research were the concepts of political communication, political participation, and leadership of Phenomenal figures with the case study of Haji Lulung, AL. SH, MH. The method used in this study was descriptive, in which the researcher described how the leadership communication style in politics is. Several things that would be explored include how the communication patterns are developed by cadres of leaders and volunteers in gaining public support, communication strategies, political messages conveyed to the public, as well as patterns and forms of leadership communication in the political scene.
\end{abstract}

Keywords-Political Communication, Leadership, Phenomenal Figure.

\section{INTRODUCTION}

In an organization or institution, it is necessary to deliver a clear message and must be understood by its members, and within the constituent party must also understand the message conveyed by the leader figure who became the leader in the party, it requires expertise or skills in doing interaction with the society, interaction can run smoothly if the leader figure is able to use communication with language that is easy to understand and clear. In his deliveryof course every leader has a different communication style.

Each communication style consists of a set of communication behaviors that are used for getting certain responses in certain situations. The appropriateness of the communication style used depends on the intention of the sender and the receiver's expectations. The communication style is influenced by the situation, not the type of person.It does not depend on the type of person but the situation at hand. Everyone will use different communication styles when they are happy, sad, angry, interested, or bored.

Likewise with someone who talks with a good friend, someone who has just known and children will talk in different styles. Besides influenced by many factors, communication style is something that is dynamic and very difficult to guess. Like culture, communication style is something relative. Several factors were identified as the cause of the communication style that is able to reflect or provide insight into interactions between individuals. According to Dianne Hofner Saphiere (2005), several factors that influencecommunication style, namely: physical conditions, roles, historical context, chronology, language, relationships, and there are also constraints in leadership that dominated by men as leaders today still so strong. Despite the fact, there are also women who have the potential that is not inferior to men in terms of leadership.

But nowadays the role of phenomenal figure cadres or already known by people who are capable and worthy of being figures as leaders is also increasingly visible in various fields, which support and care more in the fields of education, business, politics and government, we can see the gait of the leadership of leaders - figures known to the public in a variety of roles and strategic positions in people's lives. Phenomenal figures or already known by the people of Indonesia really appear to take a strategic role in leadership and sit as leaders in government. Indonesia has entrusted the leadership of a president of the sexes other than men because the figure of His phenomenon has been known by the public, namely Megawati Soekarno Putri. In addition there is Tri Rismaharini as Mayor of Surabaya and Regent of South Minahasa Tetty Paruntu, Regent of Bekasi Neneng Hasanah Yasin. Today more and more scientists or researchers are focusing on studies of how they can carry out their leadership wheels specifically. This is certainly inseparable from the complexity of the problems related to 
how to lead many people who have different character backgrounds and social status where so far there has been no agreement on how the actual existence of the leadership of famous figures and figures who are new to the public besides the man placed and studied in the perspective of political communication.

Based on this background, the author is interested in conducting this research. Successful leadership requires political communication to subordinates properly. In this case, the leadership communication style is certainly used to achieve the desired goals in an organization / institution. This phenomenon is an interesting problem to study. Based on this phenomenon, researcher is interested in bringing up the study with entitledthe Leadership Communication Style in the Political World in the Digital Age, especially in the figure of Haji Lulung, AL. SH, MH as a National Mandate Party cadre. Then this study aims to find out and analyze how the Communication Style of leaders working in the political world in this digital era, especially Partai Amanat Nasional. Through this study, it is expected to find out the style and pattern of how politicians exist in the world of national politics.

This study is expected to be able to contribute in the form of knowledge and knowledge in the study of communication science, particularly in the field of public relations, which is related to the concept and application of political communication campaigns. In addition, this study is expected to be a reference to subsequent studies related to political communication. Then practically this study is expected to contribute in the form of input to political communication activities. In addition, this research is expected to be able to describe various findings that explain what things or communication activities are recommended as well as what political communication activities are not recommended. Thus this research can help political practitioners in evaluating their political communication activities.

\section{LITERATURE REVIEW}

\section{Political Communication}

Political communication is a talk to influence in the life of the state. Political communication can also be the art of designing what is possible (art of possible) and can even be the art of designing that is not possible to be possible (Anwar. 2011: 1). Whereas Soemarno stated that the nature of political communication is the efforts of human groups who have a certain political or ideological orientation in order to control or gain power and with the aim of power, the purpose of political thought and ideology can be realized (Nora. 2014: 46).

Michael Rush and Phillip Althoff define political communication as the process by which relevant political information is transmitted from one part of the political system to another and between social systems and political systems. This process occurs on an ongoing basis and includes the exchange of information between individuals and their groups at all levels. Nimmo also stated that the scope of political communication consists of political communicators, political messages, political persuasion, the media, political communication audiences and the consequences of political communication (Nora. 2014: 46).

Political communication on a practical level presents a politically charged message managed by political actors in relation to the activities of power, authority, and policies related to political institutions. Political communication is also interpreted as part of the way to carry out functions contained in the political system, such as political socialization, political participation, political recruitment, articulation of interests, aggregation of interests, legislative processes, execution of policies, and the judiciary. This is in accordance with the opinion of Gabriel Almond, that political communication is a function that is always present in every political system. In other words, the political system will not function as it should without the functioning of political communication (Nora. 2014: 46).

Then Nimmod alam Cangara (2009), explained that political communication as a body of knowledge has elements consisting of: 1) Political Communicators. All parties involved in the process of delivering the message. These parties can take the form of individuals, groups, organizations, institutions, or government, 2) Political Messages. Political messages are statements that are delivered whether written or not, in the form of symbols or verbally containing political elements such as political speeches, laws, etc. ᄀ-others, 3) Political Channels or Media. In the current development, the mass media is considered as the most appropriate channel for conducting political communication processes, 4) Political Message Recipients. All levels of society are expected to provide a response to the message of political communication. For example by voting in elections, and 5) Effect or Influence. Effect is a measure of how far political messages can be received and understood (Nora. 2014: 50-51).

\section{Political Communication Objectives and Strategies}

Political communication aims to form and foster public image and opinion, encourage political participation, win elections, and influence state political policy or public policy. In detail, Anwar Arifin (2011) describes it as follows: 1) Political Imagery. One of the goals of political communication is to form a good political image in the audience. The political image is formed based on information received, both directly and through political media, including social media and mass media that work to 
convey general and actual political messages, 2) Public Opinion. As one of the goals of political communication, it actually is the effect of political communication, namely public opinion. Public opinion is not limited to the effects of political communication carried out by politicians or political parties, but also feedback from audiences to politicians or political parties, 3) Political Participation and Political Policy. Nimmo states that political participants are "Members of the public" who are not indifferent, but active, not only paying attention to the political messages of political communicators or politicians, but also responding to and conducting dialogues with these politicians. Even political participants work together and together with political communicators or politicians, so that they also play a role as political communicators. That is precisely political participation in the perspective of political communication, carried out by political participants, 4) General Elections (Elections). One very important goal of political communication is to win elections (general elections). The success or failure of effective political communication is measured by the number of votes obtained through clean, free, direct and secret elections (Anwar. 2011: 178).

To achieve the objectives of political communication, the process of political communication also requires the right strategy. From the explanation above, it appears that the role of the leader as a political communicator has adapted the approach of political communication strategies from Anwar Arifin (2011) which states that in the political communication strategy there are at least three suggested ways, including: 1) Personnel and Institutionality. The first step in a political communication strategy is to maintain the persona and establish the institution, meaning that the persona of a politician and the stability of the political institution in society will have their own influence in communicating, 2) Creating Togetherness. To achieve the goal of political communication, efforts are needed to create togetherness between politicians and the public (the people) by holding and composing homophile messages to the public, and 3) The third strategic step that must be taken to achieve the goal of political communication, namely to build a good consensus between politicians in one political parties and between politicians and different parties. (Anwar, 211: 235)

\section{Leadership Figure}

Political leadership plays a very important role in the effort to achieve a goal so that it is often said that the success or failure experienced by most political leaders is largely determined by the quality of leadership they have. This raises several understandings contained in political leadership, Peter G. Northouse, states that: political leadership is related to leadership as a process, in political leadership there is influence, the context of political leadership is group, there is an element of achieving goals (Alfian, 2009: 65). Then James MacGregor Burns states that the transformational leadership model essentially stresses that a leader needs to motivate his subordinates to carry out their responsibilities more than they expect. Transformational leaders must be able to define, communicate and articulate the vision of the organization, and subordinates must recognize (Venkat R. Krishnan and Ekkirala S. Srinivas, 1998: 4).

\section{METHODOLOGY}

This study used descriptive qualitative method. As Bodgan and Taylor conveyed, qualitative methodology is a research procedure that produces descriptive data in the form of written or oral words from people and observable behavior. Then descriptive qualitative research is research in which data collection in the form of words, images, and not numbers. Thus the research report will be in the form of data excerpts to illustrate the presentation of the report. The data may come from interview scripts, field notes, photographs, videotapes, personal documents, notes or memos, and other official documents. At the time of writing the report, the researcher analyzed very rich data and as far as possible in its original form (Basrowi, 2008).

By using qualitative descriptive methods, the researchers explained that leadership communication styles are certainly used to achieve the desired goals in an organization / institution. This phenomenon is an interesting problem to study. Based on this phenomenon, researcher is interested in raising research with the title Communication Style of Leadership in the Political World in the Digital Age, especially in Partai Amanat Nasional. So this research can be a reference to subsequent studies related to political communication. Then practically this research is expected to contribute in the form of input to political communication activities. In addition, this research is expected to be able to describe various findings that explain what things or communication activities are recommended as well as what political communication activities are not recommended. Thus this research can help political practitioners in evaluating their political communication activities.

Data collection techniques include interviews, observation and documentation study. The subjects in this study were Haji Lulung as Key informant, and Doni as the second informant as well as Haji Lulung assistant. As for what is explored in this study is related to two things: 1) How is the Leadership Communication Style carried out in the world Partai Politik Amanat Nasional, and 2) The pattern of communication as what is done by a leader in Partai Politik Amanat Nasional 
To analyze the data, the researcher applied the technique of data reduction, data presentation, and drawing conclusions (verification) from Miles and Huberman. The first stage, Reduction of data is field data obtained through observations and interviews and then the process of selecting, focusing attention, abstracting and transforming raw data from the field, the second is Data Presentation (Display data), namely the process of display (display) in the form of a comprehensive description on every aspect examined is completed with tables / charts, relationships between categories and the like, the last stage of verification is to interpret or interpret the data that has been compiled. Based on these interpretations, the researcher can arrange into a conclusion, where this conclusion is the result of research that can answer research questions that have been formulated previously (Irawan, 2018: 93).

Referring to this opinion, in this study the researcher will carry out the process of checking the validity of the data by interpreting the technique of comparing and checking back the degree of confidence of the information obtained by: (1) comparing observational data with interview data (2) comparing the consistency of the respondent's answers, namely by comparing what the resource person said in public for example, with what was said privately (3) comparing one's perspective, with others in his work team (Kusuma, 2018: 53).

\section{DISCUSSION}

\section{Political Communication Style}

Leadership communication is a communication process carried out by the leader (as a communicator) to the subordinates of his organization (as a communicant). In its application, leaders can use various types of leadership communication in accordance with their respective styles that are influenced by many factors. This type of leadership communication or leadership communication style must be owned by a leader. This leadership communication style must be used by leaders to influence subordinates to achieve organizational targets. This as explained by Astrid (in Rabiah, 2016) states that political communication is communication directed at achieving an influence in such a way, so that the problems discussed by this type of communication activity can bind all its citizens through a sanction determined jointly by political institutions .

Persuasive communication style, has become one of the ways used by pilgrims to face the wider public, accompanied by friendly smiles and body language, according to him what we are talking about must be in accordance with our actions in real terms. Will be unattractive when talking but not in accordance with the body directly. One of the most popular and widely applied leadership communication theories is the Like 4 system theory or 4 leadership communication styles. This theory is a managerial system theory that is based on several important variables related to managerial such as leadership, motivation, communication, interaction, decision making, goal setting, control and performance.

On the Haji Lulung Key Informant, AL.SH.MH. the author found several communication style techniques such as those in Likert theory including: first, Style Controling. This model emphasizes control over the organization. Leaders with controlling communication styles will limit and tend to regulate the behavior, thoughts and responses of subordinates. Communication that is interwoven in this style of communication is one-way communication that comes from superiors to subordinates. This one-way communication is carried out by the leader to influence his subordinates to carry out the tasks in accordance with his orders. In accordance with the style of key informants he tends to always regulate his behavior in every public speaking, when conducting campaigns, meeting with constituents, the general public and to political opponents.

Second, Equalitarian Style. This type puts forward aspects of similarity in communication. This type of leadership communication disseminates information or ideas with two-way flow, both from superiors to subordinates and vice versa. This type of leadership communication is done openly which means that every member of the organization has the right to express opinions. The leader will provide space for subordinates to provide opinions on organizational decision making. Communication is relaxed and without intimidation. In this leadership communication style, leaders have the ability to establish good relationships so that openness arises between superiors and subordinates and between subordinates. The leader is able to establish communication both formal and informal with members of the organization which will open up opportunities for each member to exchange information and ideas. Key Informant as a phenomenal figure in the writer's observation tends to hear not only from the official level, but he also wants to receive input and listen to what is conveyed from his subordinates or the general public. After that take action to find solutions to the problems conveyed, even though previously there has been action, for some of the suggestions and input added to be more perfect.

Third, Structural Force. In this leadership communication style, the leader provides information that aims to establish assignment orders, assignment schedules and organizational structure. In this communication style, the leader tries to influence subordinates by providing information related to organizational goals, work scheduling, work rules, work procedures in the 
organization. Key Informants also appreciate structural leadership, which is evident when the writer follows one of the meetings he leads, he tends to listen and give orders, receive input and then give instructions that are win-win solution. Mutual benefit between subordinates, colleagues, stake holders, mutual benefit.

Fourth, Relingushing Style. In this leadership communication style, leaders have a willingness to accept suggestions or ideas from others. Leaders are willing to reduce their desire to give orders and manage their employees. A leadership style of communication type. This can be effective if the leader works in an organization that contains people who are experienced, knowledgeable and able to take responsibility for their work. Key Informant is always open to accept constructive criticism and suggestions, even criticism that he dropped was received with a smile without replying with negative treatment. In a friendly way, done to continue the leadership performance in synergy with the public.

\section{Political Communication Strategy}

Facing the public or the public is not an easy thing, considering that the people in DKI Jakarta consist of various ethnic groups, different cultures, different social statuses, different levels of education, where the people in Jakarta can be said to be millennial modern society. Personal approach by sharing, discussion, to convey various inputs and information that is very useful to be able to compete competitively, Phenomenal Haji Lulung figure, is a figure who quickly masters the political stage.

The strategy of gathering together with youth leaders, street vendors at the Tanah Abang market, Kepulauan Seribu, etc. was carried out, to make the community feel close to no distance. At the meeting he used popular language, according to who he spoke. If with adolescents, he adjusts in direct interaction, speaking casually, listening to what is thought by millennials, what their proposals are, it is all in the diagram and answered with grammar communication that is full of control, if anyone speaks loudly, emotionally , angry, so he responded wisely. Until finally the figure of the young man who was full of enthusiasm and tends to emotion became melted and became a friend of the Lulung pilgrimage.

Communication is done besides directly dealing with constituent communities, before the campaign team conducted a survey first on the prospective constituents to be visited, after that he then made friendly visits, he also used the media in conducting campaigns, or wanted to convey a message, Online Media , Newspapers, magazines, and tabloids, other media that are used are social media such as: Twitter, Facebook, Instagram, WA Group, and Linkedin. Of the several social media used in conveying messages to the communicant in this case the public or public constituents who will see, receive the way of communication that he conveyed through social media and mass media such as television, radio, newspapers, tabloids and so forth. In addition to this strategy, there are other ways to perpetuate their communication style to successfully win the sympathy of the community, including by approaching and reaching the people of DKI Jakarta. To the Betawi tribe whose memorandum is very loyal to others, with a Betawi style dialect, the Lulung pilgrimage can pass its name up to able to drift seamlessly into a leader figure who survives to remain a idolized leader.

In addition to talking to young people, Haji Lulung also often talks with Mother-daughter. Another thing that Haji Lulung did was with the anggkot drivers. Where the city transportation drivers (angkot) in the Tanah Abang area, Central Jakarta, on Monday (29/1) 2018 that morning again carried out a mass strike. Having previously staged a demonstration in front of the City Hall building, they are now in action to close Jalan Jatibaru. As the deputy head of DKI Jakarta DPRD Abraham Lunggana alias Haji Lulung said that the Tanah Abang angkot returned to protest demanding that the road used by the street vendors (PKL) along the 400 meters be reopened.

Representatives from a French public transportation driver, to my post, he said, Bang Haji, friends of public transportation felt disadvantaged because of the presence of street vendors, "Lulung information. Previously the drivers had an audience with the Head of DKI Jakarta Transportation Department Andri Yansyah, who was then in office, then it was decided that a route would be given in the form of route modification. But not looking at it, this time the angkot drivers really demanded street vendors leave their routes. Facing this problem, Haji Lulung must be very careful in communicating, because it is wrong and if it is not appropriate to use the language style of communication, it will cause misunderstanding, which was also revealed by him during an interview with the writer at the Command Post where he had an office when he returned from the DPRD Building at that time.

He said, when the driver was angry and emotionally expressed his aspirations, demonstrated and was finally received at the DPRD, then as a people's representative I must and obligatory listen, until they impose all their objections as a driver, even though not all aspirations of the drivers are granted, but at least there are some that we really help find a way out. I just relax, because the driver's friends are also humans who are both looking for food for his wife and children. I met them, listened carefully to what they said, then I conveyed carefully how they should drive and look for passengers in the midst of the road conditions in Jakarta that were filled by street vendors, we invited both of them to find a meeting point from the chaos 
problem of pros and cons between public transportation drivers and street vendors in the Abang land market. After that, because we really did the action to help find the middle way, they got back together, understanding each other, of course this was not an easy thing, because we had to hold meetings many times to discuss this with the police, Satpol Pp. Transportation Agency and other related parties.

\section{Benefits of Political Communication}

Haji Lulung has a critical political spirit, high ideals, persistent and unyielding, it was seen immediately when the author's direct observation made during the last 6 months, when there was a polemic in Partai Persatuan Pembangunan(PPP) when it happened, he continued to struggle to show his loyalty as a politician who has a position that still wants to continue to fight for the interests of the community, with courage he resigned from Partai Persatuan Pembangunan(PPP) and he continued his struggle by taking the decision to join Partai Amanat Nasional(PAN). These efforts are demonstrated by various efforts in improving skills and always being dynamic in applying political communication styles.

$\mathrm{He}$ is persistent in improving self-quality, gain knowledge from senior figures, discussion about many things, accept criticism aimed at himself, from criticism he received, he discussed with people who have expertise in the field, it does not mean I am not understand, but I want to be better and careful in addressing every problem. In some seminar or workshop sessions I am often invited as a Speaker, but I also learn from other people, other speakers, because for me every second, every day, whenever and wherever life is learning.

As personality formers, why is that, because for me if we speak well, it is a reflection of our heart's content, and so it is better if we say the words harshly, that is also what is in the thoughts of our hearts, like when we are angry with small children, when we rebuke. With a high tone of intonation with emotions, then that's what is in our minds and hearts, if angry with children gently, that's what is in our hearts, attitude is a picture of our attitude. That is one of the expressions of Haji Lulung, AL.SH.MH. Through the political communication skills possessed by Haji Lulung, this can be beneficial for the continuation of his political career and make it easier for Haji Lulung to absorb the aspirations of the people or their constituents in this democratic era.

Democracy itself comes from the words demos and kratos. That is, the pattern of government that comes from the people. It can also be that the government (President) is elected by the people's representatives. Meaning, the highest power is in the hands of the people. Democracy is developed to foster people's participation, not the participation of a person or group. The role of the people (read: public) is more valued because it plays an important role in making decisions in the public interest. You name it, in determining a Regional Head, Regent, Governor, and President as head of state in a democratic system must be chosen by the people (Jailani, 2015). Therefore it is important for politicians to win the hearts of their constituents.

To realize a mature democratic system, high public participation is needed. But the level of participation of young people in politics is often a matter of debate. The younger generation is often regarded as the group of people who are least concerned with political issues, who often experience a breakup with their communities, who are not interested in political processes and political issues, who have a low level of trust in politicians and are cynical about various political institutions and government (Pirie \& Worcester, 1998; Haste \& Hogan, 2006). This view is often justified by data showing that there are relatively few young people who join political parties, and they tend to vote to be abstentions in elections (EACEA, 2012). Whereas the role of the young generation in political events is very important to the growth of a good democratic system.

\section{CONCLUSION}

Based on the results of research and analysis, it can be concluded as follows: 1) The communication styles used by each leader cadre were different, depending on the personal character of each, 2) The communication style used by Haji Lulung key informants is the style of language in accordance with the situation and conditions, a more careful controlling style of maintaining behavior and attitudes, 3) Promotional media used are directly to the Opinion Leader, community leaders, Ulama, members of influential cadre organizations, and 4) Media of the routine meeting held face to face

Based on the results of this study indicated that in general, the implementation of communication styles that was done very well and professionally, but there were still a few things that still noteworthy and become suggestions in this study some input, namely: 1) More emphasis on the use of appropriate Indonesian, familiarize the use of the language to broad targets, not only to certain ethnic groups, 2) The communication messages used should be more specific, so that the message delivered with a communication style that is informative, and 3) the communication style model used should be more varied so that more interesting and make public sympathy to Key Informants. 


\section{REFERENCES}

[1] Alfan Alfian, 2009 "Menjadi Pemimpin Politik", Jakarta: Gramedia Pustaka UtamaAnwar

[2] Arifin, Anwar. 2011. Komunikasi Politik: FilsafatParadigma-Teori-Tujuan-Strategi-dan Komunikasi Politik Indonesia. Yogyakarta: Graha Ilmu

[3] Basrowi. Memahami Penelitian Kualistatif. Jakarta: PT. Rineka Cipta, 2008.

[4] Dianne Hofner Saphiere et.al, 2005, Communication Highwire Leveraging the Power of Diverse Communication Styles. ISBN-10 (1931930155).

[5] Haste, H. \& Hogan, A. (2006). Beyond conventional civic participation, beyond the moralpolitical divide: Young people and contemporary debates about citizenship. Journal of Moral Education, 35(4), 473-493.

[6] Irawan, Enjang Pera. The Dynamic of the Role of Volunteer as a Political Communicator: A Descriptive Study on Volunteer's Agus-Sylvi at the Election of the Jakarta Governor 2017. Asian Journal of Humanities and Social Studies (ISSN: 2321 - 2799) Volume 06 - Issue 03, June 2018

[7] Jailani. Sistem Demokrasi Di Indonesia Ditinjau Dari Sudut Hukum Ketatanegaraan. Jurnal Inovatif, Volume VIII Nomor I Januari 2015.

[8] Krishnan, Venkat R. and Ekkirala S. Srinivas 1998, Transactional and Transformational Leadership An Examination Of Bass's (1985) Conceptualization In The Indian Context, Paper presented at Asia Academy of Management Meeting, Hong Kong, Xavier Labour Relations Institute, Jamshedpur, India.

[9] Kusuma Kurniastuti. Activities of the Cyber Public Relations of O Chanel TV in Promoting their Company on the Instagram Social Media. American Journal of Humanities and Social Sciences Research (AJHSSR) Volume-02, Issue-09,pp-50-56.2018.

[10] Nora,Ghazaly Ama La 2014. Ilmu Komunikasi Politik. Yogyakarta: ANDI.

[11] Rabiah, Sitti. Ragam Bahasa Indonesia Dalam Komunikasi Politik. The POLITICS: Jurnal Magister Ilmu Politik Universitas Hasanuddin. Vol. 2 No. 1, Jan 2016 | P-ISSN: 2407-9138. 